\title{
HOUSEHOLD SIZE AND URBAN SPATIAL CHANGE: END OF AN ERA?
}

\author{
Robert Sinclair \\ Dept.of Geography and Urban Planning, Wayne State University Detroit, \\ Michigan, 48202,U.S.A \\ e-mail: r.sinclair@,wayne.edu
}

\begin{abstract}
A dominant demographic trend of the last few decades has been the declining size of households in Western industrialized countries. Following closely upon the Baby Boom, the development became a major topic of discussion for almost two decades. The basis for, and consequences of, these changes have been well covered in the demographic literature, but their spatial implications have received less attention. Yet the, phenomenon has had a profound spatial impact at every level of the urban system. Recent statistics indicate that household size continues to decline, but does so at a rapidly decreasing rate. The present paper considers the spatial repercussions of this trend. More specifically, the paper has three aims. (1) The paper summarizes and puts into present-day perspective, a volume of research conducted a decade ago upon the spatial impact of declining household size upon the U.S. urban system (Sinclair, 1991). (2) Considers more recent demographic developments, asking whether the impact of declining household size upon the urban system is declining or coming to a close, (3) Considers other demographic developments which might he taking the place of declining household size in driving the urban system. In sum, the paper attempts to answer the question. Is an era, which has signifycantly impacted the U.S. urban system, coming to a close?
\end{abstract}

\section{HOUSEHOLD SIZE, NUMBER OF HOUSEHOLDS AND EXPANDING SPACE DEMANDS}

Two factors underly the developments discussed in this paper. One was the entry of the "baby boom" generation (the bulge) into the household-forming stage during the 1970s and early 1980s. The other was the series of' societal and attitudinal changes which influenced and served to reduce family and household size, The average number of persons per household in the United States declined from 3.38 in 1950 to reach the lowest level in history in 2,000. Although a general decline in household size in itself was not a new phenomenon 
(there was a relatively continuous decline through much of the 20th Century), what was new was the accelerated pace of the decline during the late 1960s, 1970s, and early 1980s. (Table 1). The rate of decline in household size increased from 2.6 percent from 1950-60 to no less than 11.5 percent from 1970-1980.

Table 1: Average population per household, United States, 1950-2000

\begin{tabular}{|l|c|c|c|c|c|c|}
\hline Year & 1950 & 1960 & 1970 & 1980 & 1990 & 2000 \\
\hline HHsize & 3.38 & 3.29 & 3.11 & 2.75 & 2.63 & 2.59 \\
\hline Rate of decline in Houshold size & $2,6 \%$ & $5,4 \%$ & $11,5 \%$ & $4,3 \%$ & $1,5 \%$ \\
\hline
\end{tabular}

As household size decreases, the number of households increases. It is the numbers of households, rather than their size, which has determined the various aspects of urban development discussed in this paper. Table 2 indicates the increasing divergence between the growth rates of population and numbers of households, respectively, in the period 1960-1990, a divergence, which reached a peak in the 1970s. The magnitude of the development is indicated by the fact that the numbers of households in the United States increased by more than 40 percent between 1970 and 1990, to reach a total of 92 million. Ironically, the period which scholars referred to as "slow growth", was accompanied by the greatest housing boom in U.S history.

\section{HOUSEHOLD CHANGE AND THE URBAN SYSTEM}

Changes in household size and the accompanying expansion in space demands have a significant locational impact, both within cities and throughout the urban system.

An understanding of that impact might be approached by introducing several concepts.

The Concept of household Spatial Transfer. Where a city experiences a specific decline in average household size during a certain period, it needs an equivalent increase in housing stock to maintain its population. if the city cannot accomodate that kind of growth, (i.e. provide the requisite housing stock), the growth takes place elsewhere. In essence, the repercussions of household change are "transferred" to other areas, causing a .reshuffling of the urban system at one level, and a spatial rearrangement of the metropolitan area at another level.

The Concept of Population-Household Growth Relationships. As has been seen, the rate of household change (increase or decrease) can be quite different from that of population. Moreover, the relationship between household and population growth rates vary from one period to another and from place to place. It follows that population/household growth relationships vary throughout the urban system. This variation might be looked at by considering a number of scenarios (Figure 1).

Scenarios of Population-Household Growth. Assume a period (T1-T2) of general population stability. Assume an overall decline in household size during that period. Assume first, an older city (A) whose land area is fully developed. During the period in ques- 
tion, the number of households will remain stable, but the population will decline. Assume another older city (B), which has some available space for residential expansion, but not enough to accomodate the extra households created by declining household size.

Figure 1: Population and household growth within an urban system during a period of declining household size

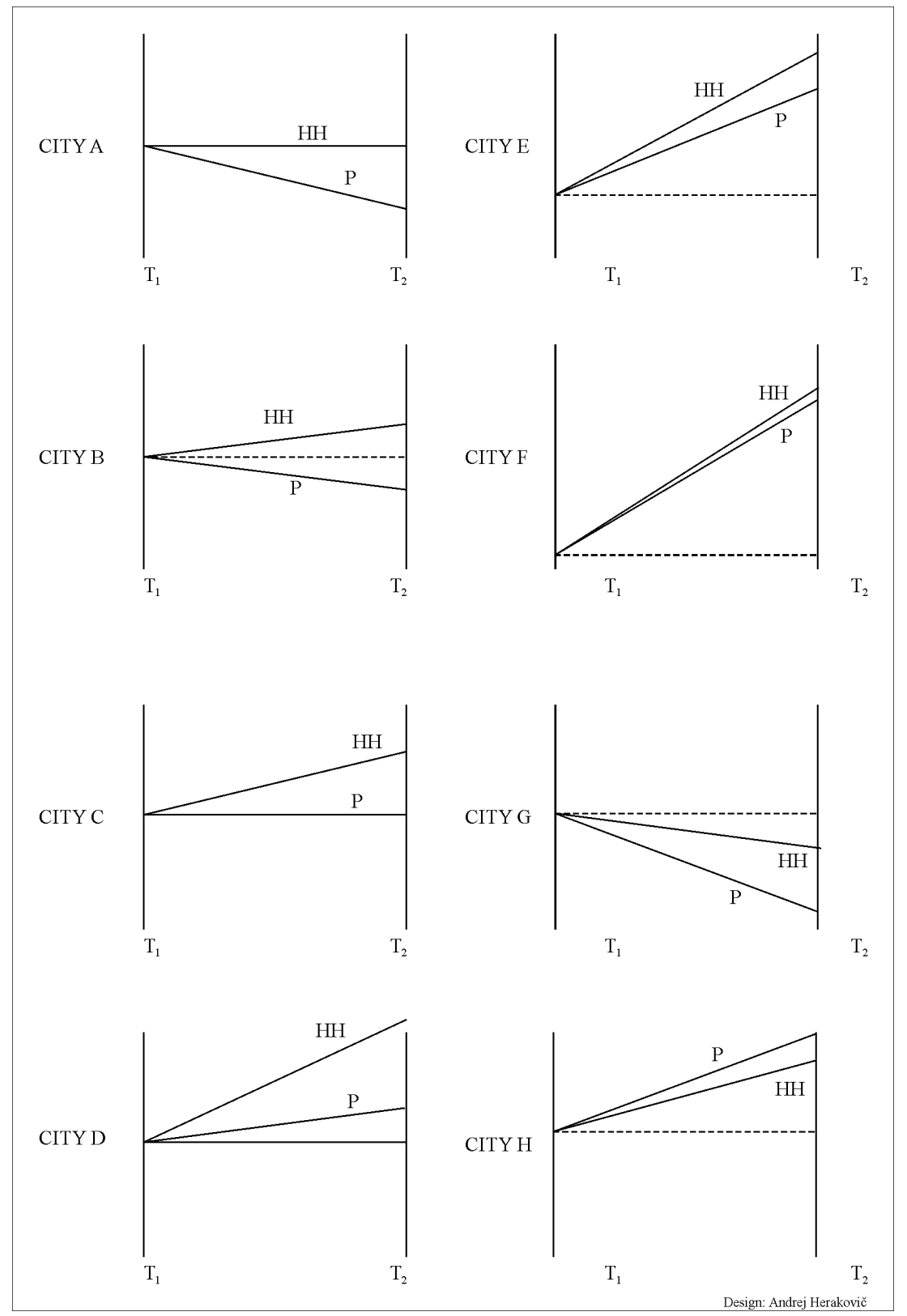


There will be an increase in number of households but a decline in population. Assume a third older city (C), in which the available space for expansion is just enough to accomodate the extra households created by declining household size. The population will remain stable, but the number of households will increase.

Assume a fourth city (D), which has more than enough room to accomodate the extra households brought about by declining household size. Moreover, the city receives some of the extra households transferred from cities A and B. Both population and numbers will increase, with the rate of household growth far exceeding that of population.

Assume another expanding city (E) with lots of space for urban expansion. The numbers of households will increase rapidly, fed by the decline in household size within its existing population, as well as by the influx of new households from cities A and B. One other development becomes apparent in situation E. Although the rate of household increase is still well above that of population increase, the difference between the two rates is considerably less than in the previous situations.

Assume an entirely new city (F). The growth of the city is entirely due to the influx of households transferred from cities A and B. Not only are there high rates of population and household growth, but the two rates of increase are identical.

Two other cities might be added to our model, by relaxing one or other of the original assumptions Assume an older city $(\mathrm{G})$ with severe population decline, brought about by factors other than declining household size. Both population and households will decline, with the rate of decline in the former far exceeding that of households. This, of course, is a situation of urban decay, as characterized by many U.S. central cities during the period.

The last city $(\mathrm{H})$ has the unique situation whereby the rate of population increase exceeds that of household increase. This is again outside the model's basic assumption, because it would not take place in a situation of declining household size. As will be seen, this situation exists in certain cities with large numbers of immigrants, whose family sizes are well above the national average.

In summary, the effect of household "transfer" is to reshuffle the urban system, by distributing a diverse set of population-household growth relationships unevenly throughout the system. Two overall corollaries might be made concerning these relationships First, the divergence between the two growth rates becomes smaller in keeping with the overall growth of the city involved. Rapidly growing areas have a greater similarity between the two rates than stable or declining areas. The second generalization concerns the cumulative effect of the transfer process upon the system as a whole. Newly developing growth areas will encompass larger share of the system's total population increase than they will of the system's household increase.

Between 1980 and 1988, the states of California, Texas, and Florida together accounted for 51 percent of the U.S. population growth, but only 35 per cent of the national growth in households. During the same period, the Northeast and Midwest accounted for 13 per cent of the national population growth, but more than 28 percent of the nation's new households. 


\section{SOME SOCIETAL IMPLICATIONS OF POPULATION HOUSE- HOLD RELATIONSHIP}

The various scenarios outlined here are related to many aspects of urban development and urban problems. For example, they have clear implications for metropolitan stability. Where population decline is associated with the loss of households, as took place in many central cities, urban decay was the result, with housing abandonment, residential and commercial blight, and social deterioration. Where population loss was not accompanied by loss of households, such circumstances did not necessarily result. For example, in most U.S. northeastern and midwestern metropolises, the majority of older suburbs have shown significant population losses in the past few decades, but little or no signs of residential decay nor abandonment. Indeed, it might be suggested that in the "slow growth " period of the 1970s and 1980s, decline and deterioration in large areas of northeastern metropolises were counteracted and literally prevented by rapid changes in household formation.

On the other hand, where there is a rapid and parallel growth of population and households, as in outlying "growth" suburbs, there is a different kind of residential instability, as an inadequate infrastructure is incapable of coping with the excessive demands put upon it. These demands become all the more acute, because a population of small households puts a far greater demand upon an area's resources and infrastructure than an equivalent population divided into larger households.

The above is only one example of the many social consequences of different population-household growth relationships, which are spread throughout the urban system. Other elements are put together in Figure 2. Categories of population-household growth relationships are arrayed, from High Population/High Household Growth to Negative Population/Negative Household Growth. In turn, these are associated with selected aspects of urban decline (row 2), service structure (row 3), fiscal fiability (row 4), traffic conditions (Row 5), and infrastructural problems (Row 6). Finally in rows 7 and 8, it is suggested how these growth relationships might be spatially distributed within the national (Row 7) and metropolitan (Row 8) urban system.

\section{POPULATION HOUSEHOLD GROWTH RELATIONSHIP IN THE U.S. URBAN SYSTEM}

Between 1980 and 1990 the population of the United States grew by 9.8 percent, whereas the number of households increased by 15.7 percent (Table 2). (As has been seen. the differential between the two rates is substantially lower than during the 1970-80 decade, when the corresponding rates were 11,55 percent and 26.7 percent). The relationship between population change and household change from 1980-90 is shown in Figure 3, which shows categories ranging from negative population/moderate household growth focussing upon the Great Lakes industrial belt to high population/higher household growth throughout much of the West and South. 
Figure 2: Societal implications of population-household, growth relationships

\begin{tabular}{|c|c|c|c|c|c|}
\hline \multirow{2}{*}{$\begin{array}{l}\text { pop-household } \\
\text { growth } \\
\text { relationship } \\
\text { (growth } 1970-85 \text { ) }\end{array}$} & $\begin{array}{l}\text { negative pop. } \\
\text { negative } h . h \text {. }\end{array}$ & $\begin{array}{l}\text { negative pop. } \\
\text { moderate } h . h \text {. }\end{array}$ & $\begin{array}{l}\text { moderate pop. } \\
\text { moderate } h . h \text {. }\end{array}$ & $\begin{array}{l}\text { moderate pop. } \\
\text { high h. h. }\end{array}$ & $\begin{array}{l}\text { high pop. } \\
\text { high h. h. }\end{array}$ \\
\hline & & & & & \\
\hline $\begin{array}{l}\text { residential } \\
\text { decline } \\
\text { (abandonment) }\end{array}$ & substantial & none & none & none & none \\
\hline $\begin{array}{l}\text { service demand } \\
\text { characteristics }\end{array}$ & $\begin{array}{l}\text { decline property } \\
\text { tax revenues } \\
\text { commercial bliget } \\
\text { empty schools }\end{array}$ & $\begin{array}{l}\text { declinig demand } \\
\text { for selected } \\
\text { services } \\
\text { empty schools } \\
\text { oversuply of } \\
\text { hospitals }\end{array}$ & $\begin{array}{l}\text { stable demand } \\
\text { for most services } \\
\text { empty schools }\end{array}$ & $\begin{array}{l}\text { high demand for } \\
\text { all services } \\
\text { new schools }\end{array}$ & $\begin{array}{c}\text { booming demand } \\
\text { for all services } \\
\text { overcrovded } \\
\text { schools } \\
\text { hospital shortage }\end{array}$ \\
\hline $\begin{array}{c}\text { fiscal revenue } \\
\text { situation }\end{array}$ & $\begin{array}{l}\text { declining property } \\
\text { tax revenues } \\
\text { declinig pop-base } \\
\text { revenues }\end{array}$ & $\begin{array}{l}\text { stable property } \\
\text { tax revenues } \\
\text { decreased pop- } \\
\text { based revenues }\end{array}$ & $\begin{array}{l}\text { increasing } \\
\text { property and } \\
\text { pop-based } \\
\text { revenues }\end{array}$ & $\begin{array}{l}\text { increasing } \\
\text { revenues }\end{array}$ & $\begin{array}{c}\text { increasing } \\
\text { revenues }\end{array}$ \\
\hline $\begin{array}{c}\text { trafic } \\
\text { congestion }\end{array}$ & none & small & moderate & severe & severe \\
\hline $\begin{array}{l}\text { infrastructural } \\
\text { problems }\end{array}$ & deteriorating & $\begin{array}{c}\text { more than } \\
\text { adequate }\end{array}$ & adequate & inadequate & $\begin{array}{l}\text { highly } \\
\text { inadequate }\end{array}$ \\
\hline $\begin{array}{l}\text { relevant part } \\
\text { of metro system }\end{array}$ & $\begin{array}{l}\text { central city } \\
\text { selected older } \\
\text { suburbs }\end{array}$ & $\begin{array}{l}\text { traditional and } \\
\text { post-war } \\
\text { suburban ring }\end{array}$ & $\begin{array}{l}\text { traditional and } \\
\text { newer suburbs }\end{array}$ & $\begin{array}{c}\text { new seuburbs } \\
(1970-80 \\
\text { expansion) }\end{array}$ & $\begin{array}{l}\text { growth areas } \\
\text { metropolitan } \\
\text { periphery }\end{array}$ \\
\hline $\begin{array}{l}\text { relevant part } \\
\text { of U. S. system }\end{array}$ & $\begin{array}{l}\text { selected older } \\
\text { industrial cities }\end{array}$ & $\begin{array}{l}\text { northeast and } \\
\text { great lakes } \\
\text { industrial belt }\end{array}$ & $\begin{array}{c}\text { selected areas } \\
\text { of medwest and } \\
\text { east }\end{array}$ & $\begin{array}{l}\text { west } \\
\text { south }\end{array}$ & $\begin{array}{c}\text { west } \\
\text { southwest } \\
\text { florida }\end{array}$ \\
\hline
\end{tabular}

Table 2: Percentage growth in population and numbers of households, US, 1950-2000

\begin{tabular}{|l|c|c|c|c|c|}
\hline Year & $1950-60$ & $1960-70$ & $1970-80$ & $1980-90$ & $1990-00$ \\
\hline \multirow{2}{*}{ Population } & 152271000 & 180671000 & 205052000 & 226546000 & 248709873 \\
\cline { 2 - 6 } & 180671000 & 205052000 & 226546000 & 248709873 & 281249908 \\
\hline \multirow{2}{*}{ Househop. growth } & $19,0 \%$ & $13,3 \%$ & $11,5 \%$ & $9,8 \%$ & $13,2 \%$ \\
\hline $\begin{array}{l}\text { \% household } \\
\text { growth }\end{array}$ & 4350000 & 52600000 & 63500000 & 80400000 & 91900000 \\
\cline { 2 - 6 } & $23,7 \%$ & $19,7 \%$ & $26,7 \%$ & $15,7 \%$ & $14,7 \%$ \\
\hline
\end{tabular}

The resulting pattern is not analyzed in this paper, but two points might be noted. First, as might be expected, the divergence between population and household growth is much greater 
in the slow-growth areas of the Northeast and Northcentral areas than in the high-growth areas of the South and West. Secondly, it is appropriate to look at these population-household ratios in relation to declining household size within the system as a whole. Some thought-provoking questions might be asked. How much of the growth in the South and the West might simply represent the spatial "transfer" of added households created by the system as a whole? More provocatively, how much of the the growth in the Sunbelt in the 1970s and early 1980s would have (or would not have) occurred if household size in the nation had remained at its 1970 levels?

\section{POPULATION HOUSEHOLD GROWTH RELATIONSHIPS IN A METROPOLITAIN SETTING}

The Detroit Metropolitan area is representative of a large metropolis with a stagnating population- a common situation in eastern and midwestern metropolises during the 1970 s and 1980s. The area's population declined by 1.5 percent between 1980 and 1990, whereas the number of households increased by 61 percent. (Corresponding figures for the 1970-80 decade were +1 and +14 percent respectively). The population/household growth relationship varied greatly throughout the metropolitan area (Figure 4).

The spatial pattern is relatively clear: (A) A central area of both population and household decline. The area comprises the Central City and several adjacent suburbs, which showed much evidence of urban abandonment and blight. (B) An arc of suburbs surrounding the central cities, with considerable population decline and moderate household growth. These suburbs, comprising much of the early postwar suburban development, are probably most representative of many of the factors discussed in this paper. Overall, there is no sign of housing abandonment nor physical deterioration, although there are significant changes in the structure of demand for services. (C) A band of scattered suburbs, showing moderate growth in population and a somewhat higher growth in number of households. In many respects, they represent the most stable part of the metropolitan area. (D) A broad area of suburbs stretching into the metropolitan periphery, with high to moderate population growth and high household growth. They were the boom areas of the metropolitan system, with high demand for all services and an infrastructure often incapable of accommodating such rapid development. Of pertinence to this paper is the fact that, although some of this growth represents household loss in the central area, most (more than 80 percent between 1970 and 1980) of the growth can be attributed indirectly to the high rate of household formation in the metropolitan area as a whole, which has been "transferred" into this area. To identify the growth simply as migration from the more central area is only part of the story.

The decades of the 1970s and 1980s constitute one of the most significant periods of urban spatial expansion in United States history. Unlike previous periods of expansion, the 1970-90 period was not triggered by rapid population growth. Rather, it was associated with dramatic changes in household composition and household size. During this period the nature of urban development varied through the urban system, largely in keeping with the relationship between the rates of population growth and household growth at any one place. 
In turn, each of those relationships brought its respective set of urban changes and social problems. In sum, focussing upon population and household growth relationships, and the varied consequences of those relationships, provides a spatial framework for looking at a diversity of urban development characteristics and problems of the 1970-1990 era.

\section{Figure 3: Change in population and households 1980-1989}

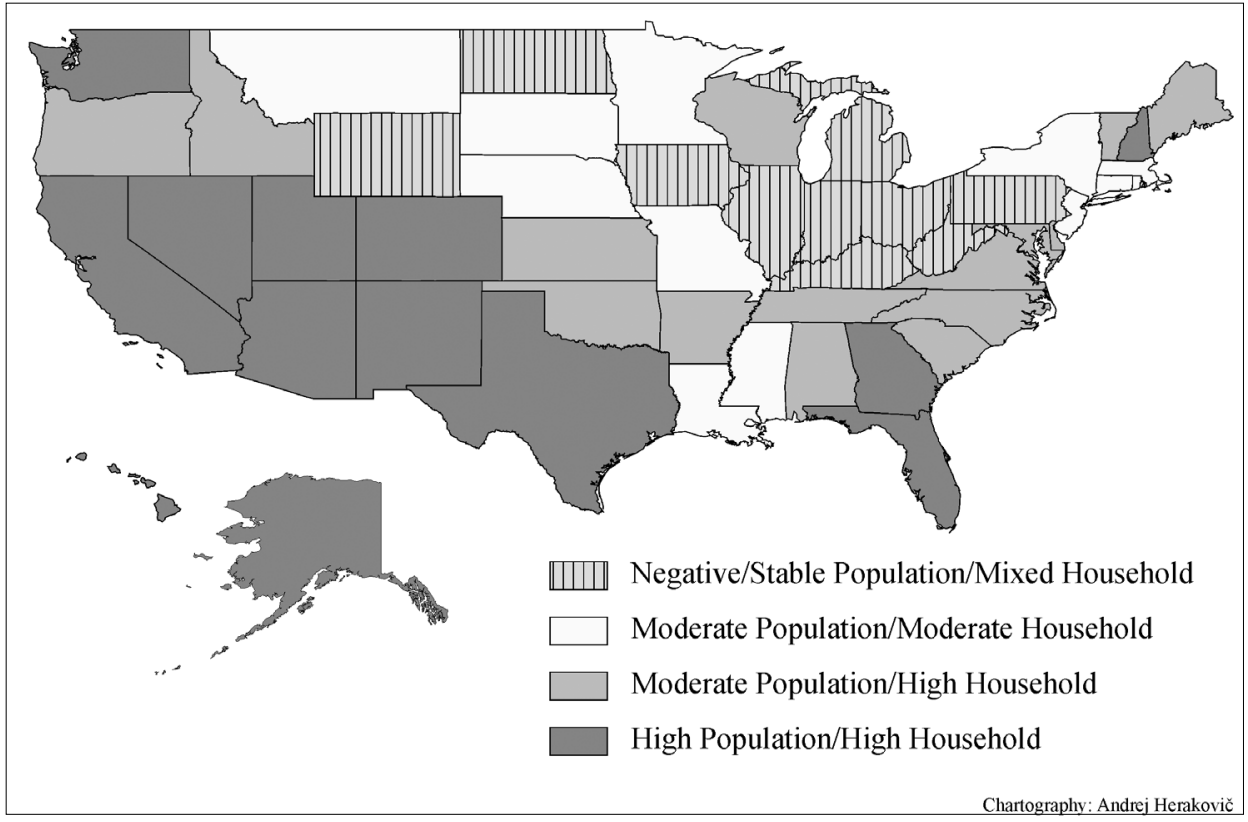

\section{HOUSEHOLD GROWTH AND THE FUTURE: EMERGING TRENDS}

During the 1990s, and continuing into the new century, major demographic changes are taking place, which have a direct bearing upon the developments discussed in this paper. Essentially, the two factors, which triggered the developments discussed in this paper, no longer are present. First, the "Baby Boom" generation (the "bulge" in the demographic profile) is well beyond the household-forming stage. Secondly, although the societal and attitudinal changes which led to a reduction in household size are still present, there would seem to he some point at which this reduction must diminish and go no farther.

The emerging trends are indicated in the period from 1990-2000.(Table 1).

During this decade, the average size of households in the United States continued to decline (from 2.63 persons in 1990 to persons to 2.59 in 2000). What is significant, however, is the low rate of this decline $(1.5 \%)$, which is smaller than at any period in the last half-century, and a striking contrast with the high rates of the previous two decades. 
The recent trend in household size is accompanied by equally striking changes in the relationship between numbers of households and population (Table 2).

Between 1990 and 2000, the U.S. population increased by 33 million persons, the largest numerical increase in history and the largest percentage increase (13.2 per cent) since the baby boom. During the same period, the number of households increased by over 13 million, a percentage increase of 14.7 per cent. These figures indicate two striking developments. First, although there was a large increase in households in keeping with the large population increase, the rate of household increase (14.7 per cent) was lower than at any time in the last fifty years. Secondly, there was striking convergence between the rates of population growth and of numbers of households, to the degree that the two rates were almost similar (13.2 per cunt and 14.7 percent respectively). This convergence of growth rates is all the more remarkable, in view of the great divergence between those rates during the previous (1970-80 and 1980-90) two decades.

These demographic developments during the 1990-2000 decade would seem to indicate that the period of declining household size (and the spatial repercussions discussed in this paper) might be drawing to a close. If this is indeed true, it raises two important questions. First, how will the impact of this development he distributed through the urban system'? Secondly, what other demographic developments might be taking the place of declining household size in driving the urban system?

\section{POPULATION HOUSEHOLD GROWTH RELATIONSHIPS IN THE U.S. URBAN SYSTEM. EMERGING TRENDS}

As has been seen (Table 2), between 1990 and 2000 the United States population increased by 13.2 percent, whereas the number of households increased by 14.7 percent. As in previous decades, there is considerable variation throughout the system, from population/household growth ratio of 3.8 to 11.4 in the state of Maine to 13.8 to 10.8 per cent in California. Most notably, however, there are six states in which the population growth rates are higher than those of households, and a similar number of states where the two rates are almost identical.

The overall national pattern of population-household growth relationships is illustrated by a comparison of the nine U.S.Census districts ( Table 3). The pattern has some similarities to that of previous decades (Figure 3), with a greater divergence between the two rates in slower-growing Northeast, Midwest and Southeast parts of the country than in the rapidly growing Southwest and West.

The overall similarity of the above pattern with previous decades, however, obscures two fundamental differences from those decades. One concerns the situation in the northern and eastern areas of the country. Here, although household growth rates continue to be greater than population growth rates, the divergence is quite moderate in virtually all parts of the area. It would seem that the number of households available for "household transfer" to other areas is rapidly diminishing. 
The second major difference is observed in the Southern and Western parts of the country. Those areas received a major part of the country's remarkable growth during the 1990s, leading to exceedingly high rates of both population and household growth. This growth was accompanied by a convergence of the two growth rates. Indeed, in the Mountain Division the two growth rates are virtually the same, whereas in the Pacific Division, the population growth rate exceeds that of households. It is clear that very little of the growth in this part of the country can be attributed to declining household size in the system as a whole.

Table 3: Growth in population and number of households, 1990-2000. US census regions and divisions

\begin{tabular}{|r|r|r|r|r|}
\hline \multirow{2}{*}{ Area } & \multicolumn{2}{|c|}{1990} & \multicolumn{2}{|c|}{2000} \\
\cline { 2 - 5 } & population & household & population & household \\
\hline United States & $248,709,873$ & $91,947,410$ & $281,421,906$ & $105,480,101$ \\
\hline \hline Northeast & $50,809,229$ & $18,872,713$ & $53,594,378$ & $20,285,622$ \\
\hline N. England & $13,206,943$ & $4,942,714$ & $13,922,517$ & $5,387,114$ \\
\hline Mid-Atlantic & $37,602,286$ & $13,929,999$ & $39,671,861$ & $14,898,508$ \\
\hline Midwest & $59,668,632$ & $22,316,975$ & $64,392,776$ & $24,734,532$ \\
\hline E.N. Central & $42,002,942$ & $15,596,590$ & $45,155,037$ & $17,244,063$ \\
\hline W.E. Central & $17,659,690$ & $6,720,385$ & $19,237,739$ & $7,490,469$ \\
\hline South & $85,445,930$ & $31,822,254$ & $100,236,820$ & $38,015,214$ \\
\hline S. Atlantic & $43,566,853$ & $16,503,063$ & $51,769,160$ & $19,973,752$ \\
\hline E.S. Central & $15,176,284$ & $5,651,671$ & $17,022,810$ & $6,607,066$ \\
\hline W.S. Central & $26,702,793$ & $9,667,520$ & $31,444,850$ & $11,434,396$ \\
\hline West & $52,786,082$ & $18,935,468$ & $63,197,932$ & $22,447,430$ \\
\hline Mountain & $13,658,776$ & $5,033,336$ & $18,172,295$ & $6,711,902$ \\
\hline Pacific & $39,127,306$ & $13,902,132$ & $45,025,637$ & $15,732,831$ \\
\hline
\end{tabular}

\begin{tabular}{|r|r|r|r|r|r|}
\hline \multirow{2}{*}{ Area } & \multicolumn{2}{|c|}{ \% Change } & \multicolumn{2}{c|}{ Household size } & \multirow{2}{*}{ \% change } \\
\cline { 2 - 5 } & population & household & 1990 & 2000 & \\
\hline United States & 13,2 & 14,7 & 2,63 & 2,59 & $-1,52$ \\
\hline Northeast & 5,5 & 7,5 & 2,61 & 2,56 & $-1,92$ \\
\hline N. England & 5,4 & 9,0 & 2,58 & 2,50 & $-3,10$ \\
\hline Mid-Atlantic & 5,5 & 7,0 & 2,62 & 2,58 & $-1,53$ \\
\hline Midwest & 7,9 & 10,8 & 2,60 & 2,53 & $-2,69$ \\
\hline E.N. Central & 7,5 & 10,6 & 2,63 & 2,55 & $-3,04$ \\
\hline W.E. Central & 8,9 & 11,5 & 2,55 & 2,49 & $-2,35$ \\
\hline South & 17,3 & 19,5 & 2,63 & 2,56 & $-1,92$ \\
\hline S. Atlantic & 18,8 & 21,0 & 2,56 & 2,52 & $-1,56$ \\
\hline E.S. Central & 12,2 & 16,9 & 2,62 & 2,50 & $-4,58$ \\
\hline W.S. Central & 17,8 & 18,3 & 2,69 & 2,67 & $-0,74$ \\
\hline West & 19,7 & 18,5 & 2,72 & 2,75 & 1,10 \\
\hline Mountain & 33,5 & 33,3 & 2,65 & 2,65 & 0,00 \\
\hline Pacific & 15,1 & 13,2 & 2,74 & 2,79 & 1,82 \\
\hline
\end{tabular}




\section{EVOLVING FACTORS OF DEMOGRAPHIC CHANGE IN U.S. URBAN SYSTEM}

The changing national patterns of population-household growth relationships during the 1990-2000 decade can only be understood by relating them to some revolutionary demographic changes, which took place during that period. Those changes have had the greatest impact upon the Southern and Western parts of the country.

First, the South and West arc the growth areas of the country, claiming a major share of the country's remarkable growth during the period. In the 1990-2000 decade, the Southern states accounted for 45.2 percent of the national growth in population and 45.7 percent of the national household growth. At the same time, the Western states encompassed 31.8 percent of the nation's population growth and 25.9 percent of the national household growth. As has been seen in Figure 1, it is in new growth areas that the household-population growth lines converge. This is particularly true of the Mountain states, which had the largest percentage population growth in the country.

Secondly, it is the Southern and Western states which have been most impacted by the revolutionery increase in immigration (from Latin America and Asia), which bulged in the late 1980s and continue into the present. Those immigrants and their offspringhave larger families (nuclear and extended) and hence households, than their non immigrant counterparts. It is this factor, which largely accounts for the Western states having higher population growth rates than household growth rates during the 1990-2000 decade.

Together, the two demographic factors discussed here largely explain the convergence of population-household growth rates (and the increase in household size) in the South and West of the United States during the 1990-2000 decade. It is clear that "\{household transfer" from other parts of the system played only a minor role.

The slower-growth areas of the Northeast and Midwest have not been as greatly impacted by the demograhic developments, which have taken place in the South and West. Overall, the moderate divergence between population and household growth rates in those areas would appear to he in keeping with what demographers have termed the "aging in place" of the baby boom generation. In this respect, two observations might be made. One is that the divergence in population/household growth rates ( and the decrease in household size ) are greater in the more peripheral, and less urbanized, parts of the region (e.g.. the states of Alabama, Kentucky, Maine, and North Dakota). Secondly, the greatest convergence in the two rates (and the smallest decrease in household size) is taking place in highly urbanized areas with a significant presence of new immigrants (e.g. the states of Illinois, New York and New Jersey).

\section{EMERGING POPULATION HOUSEHOLD GROWTH RELATIONSHIP IN A METROPOLITAIN SETTING}

Although the present paper does not attempt to analyze recent population-household growth relationships at the metropolitan level, a few observations might be made based upon the metropolitan Detroit region. 
Overall household size in the Detroit region decreased by 3.2 percent (from 2.67 to 2.58) between 1990 and 2000. This decrease is considerably less than in the 1970-80 and $1980-90$ decades. During the $1990-2000$ period, the metropolitan population increased by 4.1 per cent, whereas the number of households increased by 7.3 per cent. Again, the divergence between the two rates is considerably less than in the previous two decades.

The spatial pattern of population/household growth rates bears some resemblance to that in the previous decades (Figure 4), with a greater divergence between the two rates in the inner suburban areas and a greater convergence in the outer and developing suburbs . However, a number of differences from the preceding decades might be noted.

Figure 4: Detroit metropolitan area, change in population and households, 1980-1990

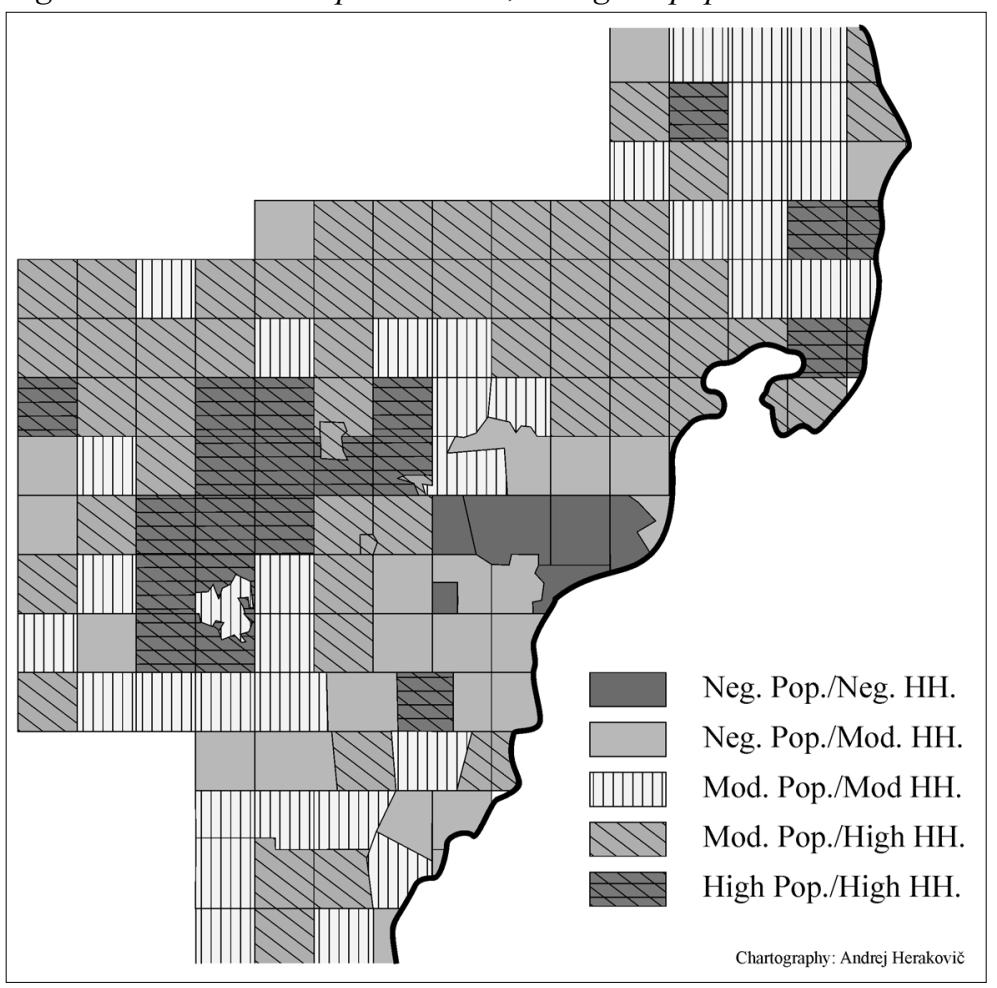

The most notable development is the increase in household size in the central cities of Detroit and certain nearby suburbs., reflecting a striking convergence of population and household growth rates . (To a large degree, those areas correspond to the centers of of decline and decay discussed in a previous section). The household changes in those areas are closely related to fact that those are the main areas of Middle Eastern and Hispanic immigration, which increased significantly during the 1990-2000 period.

It is beyond the scope of this paper to analyze these recent trends. However, it is tempting to visualize a developing situation of increasing or stable household size (with 
converging population-household growth rates) in two widely separated areas of the metropolis, namely: (a) the central cities and inner suburbs and (b) the newly developing outer suburbs. In between those two areas is (c) an area of continued declining household size, reflecting the "aging in place" of middle-class intermediate suburbs.

\section{CONCLUSION}

The decades of the 1970s and 1980s constitute one of the most significant periods of urban spatial expansion in U.S. urban history. In contrast to previous periods of expansion; the 1970-90 period was not triggered by rapid population growth. Rather, it was largely associated with dramatic changes in the size of households. During this period the nature of urban development varied throughout the urban system, largely in keeping with the relationship between population growth and household growth at any particular place. In turn, each of these relationships brought its own set of urban changes.

During the 1990s, and still to-day, household size continues to decline, but at a rapidly decreasing rate. At the same time, other demographic developments have assumed a predominant place in driving the U.S. urban system It would seem that the era discussed in this paper is rapidly drawing to a close. At the same time, the spatial developments asociated with that era will have a lasting effect upon the U.S. urban system.

\section{References}

Sinclair, R., 1992: "Demographic Change and Urban Restructuring Within the United States Urban System", Investigaciones Geograficas (Special Issue), Mexico City. 